STUDIA PRAWNO-EKONOMICZNE, t. CV, 2017

PL ISSN 0081-6841; e-ISSN 2450-8179 $\quad$ s. 341-363

DOI: $10.26485 /$ SPE/2017/105/19

\title{
Richard POSPISIL*
}

\section{THE MONETARY AGGREGATES AND CURRENT OBJECTIVES OF EUROPEAN CENTRAL BANK ${ }^{1}$}

\begin{abstract}
(Summary)
Current quantitative easing brought into monetary policy of central banks unprecedented influence on monetary equilibrium and monetary policy as a whole. The issue of money and establishing interest rates are the main activities of central banks. Through issuing of money, the central banks immediately influence the behaviour of households, companies, financial markets and the state with measurable impact on main economic outcomes. The monetary policy strategy of the European Central Bank requires identification of a monetary aggregates which is a stable and reliable indicator of inflation over the medium term. This is closely related to growth of real GDP and the rate of unemployment. When monitoring the issue of money, it is necessary to focus not only on its volume, but also on the attributes and functions carried by money. The objective of the paper is to analyse the indivual monetary aggregates of issued money in the eurozone, their different effect on economy with a major impact on medium term growth of real domestic outcome. The paper deals with the denomination of the aggregate to its various elements within European Central Bank, which is significant for fulfilling its monetary policy targets.
\end{abstract}

Keywords: monetary aggregates; monetary policy; inflation; GDP; Europaean Central Bank

JEL Classification: E50, E58

\section{Introduction}

The current economic crisis is primarily a budget and debt one. Nevertheless, together with public budgets and public debts, the issues of monetary policy have been continually and broadly discussed and thought out. Central banks issue

* Assoc. Prof., Palacky University of Olomouc, Department of Applied Economics, Krizkovskeho 12, 771 80, Olomouc Czech Republic; e-mail: richard.pospisil@upol.cz

1 Work of this paper was supported by the grant of Faculty of Arts, Palacky University of Olomouc No. IGA_2017_011 Continuities and Discontinuities of Economy and Management at Past and Present. 
money and govern short-term interest rates and thereby influence the behaviour of financial markets, wealth, real outcome, employment and also prices.

Even after several decades of real functioning of central banking it is possible to find a schematic simplifying of monetary policy, the consequence of which is that the monetary approach has been increasingly oversimplified and mixed up with the regulation of the amount of money in the economy. Other aspects of monetary policy, especially the functioning and attributes of money, its velocity of turnover or the use of regulations of short-term interest rates, have been missed out - maybe due to a difficult and sometimes ambiguous understanding of their content. Money in circulation needs to be monitored not only from the point of view of its volume, but also from the point of view of the functions it carries.

Studying monetary aggregates can generate a lot of information about the financial stability and overall health of a country. For example, monetary aggregates that grow at a pace that is too rapid may cause fear of overinflation - if there is a greater amount of money in circulation to be used on the same amount of goods and services, prices are likely to rise in response - which is a common example of the law of supply and demand. If this occurs, central banking groups are likely to be forced to raise interest rates or stop the money supply growth in some way.

For decades, monetary aggregates were essential for understanding a nation's economy and were key in establishing central banking policies in general. The past few decades have revealed that there is a lower connection between fluctuations in the money supply and significant metrics like inflation, as well as gross domestic product (GDP) and unemployment. As of 2016, the central bank's monetary policy is better understood by looking at the amount of the money the bank is releasing into the economy with imminent influence on GDP growth.

\section{Objectives and Methods}

The issue of monetary aggregates is part of a broad range of issues related to money supply and money market management. Although this is a very old issue, problems of structure of individual monetary aggregates on inflation targeting and growth of GDP are still not yet fully explored. The paper at the beginning describes the development of views on money and financial thinking from historical perspective and so laying the basis for the advanced analysis of equation of monetary equilibrium. 
The analysis is based on the monetarist concept of monetary equilibrium Fisher's equation of exchange and deeply focuses on current contemporary theory and practice of monetary aggregates of central banks. The main objectives of the article is to analyze functions of individual monetary aggregates in Europaen Central bank balance sheet and evaluates their wide different influence on monetary equilibrium and selected economy variables, especially the growth of real GDP. This analysis also takes into account the contradictory of the objectives of monetary policy and consequently using different instruments of the monetary policy portfolio.

In conclusion paper summarizes analyzed findings and applies them to the modern current monetary policy objectives - primarily the price stability and balanced economic growth and high level of employment. The competent issue of money and regulation of the monetary aggregate $\mathrm{M}$ represents the most efficient monetary policy tool aiming at economic recovery and sustainable growth.

\section{Views on the Theory of Money Equilibrium}

The first views related to the quantity monetary thinking appeared more than four centuries ago in connection with the increasing inflow of gold and silver from overseas to Europe. Several philosophers of that time noticed that together with the growth of gold and silver in circulation, prices also grew up.

The first one who tried to give scholarly reasons for the quantity approach to money was the English philosopher, economist, state theorist and jurist John Locke. In 1691, he summed up his interpretation of money supply and its functioning in circulation in five chapters of his pamphlet "Some Considerations of the Consequences of Lowering the Interest and Raising the Value of Money". As an economist - mercantilist he resulted from the generally widespread and accepted identification of money and precious metals. In consequence of precious metal imports to Europe and the increasing mining of precious metals on European fields, he asked himself the question of how much money should actually be in circulation. Even at that time he mentions that it is difficult to define the exact and ideal supply of money in circulation as its function in the economy is affected not only by its volume but also by the velocity of its turnover ${ }^{2}$.

2 N. Barbon, A discourse concerning the new money lighter: in answer to Mr. Lock's Considerations about raising the value of money, 1971. 
Moreover, Locke assumes that not all the money in circulation really circulates; a part of money is kept for the so-called bad times, or can be taken abroad. Related to this, he was the first to suppose that the decrease of money has no significant impact on monetary circulation as it is equalled by faster turnover of money. At the very beginning of his paper he divides money into its particular forms according to the purpose of its use and the velocity of turnover, i.e. money for landholders, money for labourers and money for brokers. Therefore he was the first to discuss the issue of money denomination into particular monetary aggregates, which has been very topical and discussed so far.

Fifty years later the Scottish enlightenment philosopher and economist David Hume became the first true author of the quantity theory of money in the presentday meaning. He sophisticatedly connected the conclusions and findings of many of his predecessors into a united social and economic theory. He published his views in the volume "Political Discourses" in 1752. Pricing is not related only to the value ratio of precious metals, or metal money, and goods, but it is significantly affected by the supply of money in circulation. Increasing the supply of money leads to the increase of prices and to the increase of outcome only in a short-term perspective, whereas in the long-term perspective the real product remains unchanged. In his work "Four Dissertations", which was published as a part of "Essays and Treatises on Several Subjects" in 1757, Hume argues that increasing the supply of money has no other impact than increasing the price of work and goods. In the process towards this change, such increase may have an impact on the economy as it may stimulate industry, but after the changes settle down, there is no impact at all. As the first author he precisely formulated the quantity theory of money and the derived theory of interest rate ${ }^{3}$. Therefore he directly influenced John Maynard Keynes, one of the greatest economists of the $20^{\text {th }}$ century.

David Ricardo was another significant economist who, besides Adam Smith, Thomas Malthus and John Stuart Mill, became one of the most significant representatives of the British school of political economics. In his collection "On the Principles of Political Economy and Taxation" from 1871 he drew the conclusion that the value of money from precious metals is affected not only by its volume but also by the costs of mining the metals and production of money from the metals. On the other hand, the value of paper (non-substance) money, the issue of which was spreading at that time, depends only on its amount. Decreasing the amount can increase its value and vice versa. In Chapter 27 "On Currency

3 J. Fieser, David Hume - Essay, Moral, Political and Literary, 2006. 
and Banks" he discusses the equilibrium of the supply of money in circulation and the amount of offered goods. He also says that any disequilibrium has to be treated by the Bank of England by means of adjustment of its issuing activity. Ricardo united the quantity theory of money and the in-progress theory of value into a comprehensive theory and it is regarded as the peak of the English political economics ${ }^{4}$.

\section{Equation of Monetary Equilibrium}

The above-mentioned brief overview can be, as most economic relations and associations, summed up into a mathematical equation. At the end of the $19^{\text {th }}$ century some economists attributed its primacy to the well-known American astronomer and economist Simon Newcomb who in his work called "Principles of Political Economy", published in 1885, discusses the "equation of exchange of money and goods"s. The first author who published the equation in the form known today was the outstanding American economist Irving Fisher who did so in his work "The Purchasing Power of Money: Its Determination and Relation to Credit, Interest, and Crises", published in 1911. The works of Irving Fisher are considered to be the beginning and basis of monetarism and his notation of the equation is as follows:

$$
\mathrm{MV}=\mathrm{PT}
$$

where $\mathrm{M}$ is the nominal amount of money, $\mathrm{V}$ is the velocity of money turnover (circulation) which defines how many times during the period in view one euro is on average used for purchasing goods. On the right side of the equation $\mathrm{P}$ defines the average price of goods and services (in this case the price level) and $\mathrm{T}$ represents the number of transactions. Fisher is his original version of the equation used $\mathrm{T}$ for expressing all transactions, i.e. for purchasing the final production of goods and services, for purchasing intermediate goods and for purchasing capital transactions, i.e. in a broader sense for purchasing land and capital. In the present-day form $\mathrm{T}$ involves only the final production of goods and services and therefore $\mathrm{T}$ is substituted by $\mathrm{Q}$ (the real product) and the form of the equation is as follows:

$$
\mathrm{MV}=\mathrm{PQ}=\left(\mathrm{p}_{1} \mathrm{q}_{1}+\mathrm{p}_{2} \mathrm{q}_{2}+\ldots\right)
$$

\footnotetext{
T. Sowell, On classical economics, 2006.
}

5 M. Friedman, Money mischief, 1997. 
Every purchase may be seen as an entry in the double-entry bookkeeping in two different ways. On one hand as the amount of money spent and on the other hand as the amount of goods and services (multiplied by their price) purchased. The left side of the equation represents the supply of money and the right side of the equation represents the supply of goods, or money demand.

According to Fisher, the equation implies the following conclusions:

- prices change direct proportionally to the amount of money in case the amount of purchased goods $\mathrm{Q}$ and the velocity of money circulation $\mathrm{V}$ remain unchanged,

- prices change direct proportionally to the velocity of money turnover (circulation) in case the amount of money $\mathrm{M}$ and the amount of purchased goods $\mathrm{Q}$ remain unchanged,

- prices change in the opposite proportion to the amount of purchased goods $\mathrm{Q}$ in case the amount of money $\mathrm{M}$ and the velocity of its turnover $\mathrm{V}$ remain unchanged.

From the above conclusions, Fisher also deduced the impact of the change of money on nominal and real quantities. Provided that $\mathrm{V}$ is stable (the economy is in equilibrium and $\mathrm{V}$ is determined by payment conventions and technologies) and $\mathrm{Q}$ is independent on the supply of money in circulation and on price (the economy fully uses its disposable resources and finds itself close to its potential with full employment), the changes in the supply of money in circulation M lead only to the changes of the price level, i.e. an increase of money supply results in the same increase of the price level ${ }^{6}$. The total output of an economy is determined by productivity, labor force participation and changes in employment. For the equation, we look at real output against potential output. We must look at GDP in terms of real and nominal GDP ${ }^{7}$.

Monetary equilibrium is a situation where the supply of money equals the demand, given a particular constellation of prices. The supply of money includes both the monetary base and various forms of credit. In monetary equilibrium, the monetary system is doing the most it can to facilitate beneficial trades. An excess supply of money induces people to make some trades that market participants will later judge not to have been beneficial. A deficient supply of money hinders people from making some beneficial trades ${ }^{8}$.

6 M. Friedman, Money mischief, 1997.

7 B. Twomey, The Taylor Rule: an Economic Model for Monetary policy, Economics basics, Chicago 2017.

8 K. Schuler, Monetary Equilibrium - the Goal of Monetary Policy, The Fed and Central Banks, New York 2011. 
The logical consequence of the above is the so-called neutrality, or the super neutrality of money, which means that money does not affect the real quantities of the economy (real product and unemployment rate) but only the nominal ones (price level, nominal product, or both). Money is regarded as neutral in case the money supply has no long-term impact on the real interest rate, real product and real monetary rate because the above-mentioned quantities in their nominal amount exchange one to one to the nominal amount of the money supply. The only result of a supply shock on the side of the money supply change (increase) is only the increase of the price level. Money is regarded as super neutral in case that permanent changes of the money supply have no long-term impact on the real interest rates, real product and the rate of its growth and the real monetary rate because the inflation rate and the above-mentioned quantities in their nominal amount change one to one to the nominal amount of the money supply. In this sense, super neutrality is discussed with regard to the real revenue (standard of living) and with regard to the rate of growth of real revenue (economic growth) ${ }^{9}$.

The impact of inflation increase on relative demand for money and capital can be illustrated by the so-called Tobin effect which is based on the premise that a part of the property portfolio of economic entities is both money and physical capital. Increasing the rate of inflation at the given real return of capital leads to the decrease of money attractiveness and increase of capital attractiveness which in consequence leads to the revaluation of portfolio structures. The higher rate of inflation then corresponds with higher stock of capital and in consequence with the increase of real revenue. What also plays a fundamental role is the aversion of households towards saving risks and the legal deposit insurance. In a standard market economy, the rate of inflation and the rate of economic growth are expertly set by the mix of monetary and fiscal policies. Changes of the monetary policy affect the flow of government revenues, which in consequence affects changes in the fiscal policy. If economic entities suffer from high aversion towards risk, then changes in the fiscal policy are manifested by the fact that high rate of inflation is related to slow economic growth (stagflation). If the economic policy is transparent and trustworthy and risk aversion is low, the result may correspond with the presumption of the Tobin effect ${ }^{10}$.

As regards monetary policy, Fisher was the first economist to clearly and consequently distinguish between the real and nominal interest rates. The so-called Fisher effect deals with the change of the real interest rates depending on the

9 J. Frait, R. Zednicek, Monetární politika, neutralita a superneutralita peněz, 2001.

10 J. Tobin, The Interest Elasticity of Transaction Demand for Cash, 1956. 
amount of the nominal interest rates and inflation. Generally the real interest rates are considered to be nominal interest rates minus inflation. According to Fisher, the mutual relation is more complex. The real interest rate $r$ is defined as follows:

$$
r=[(1+i) /(1+\pi)]-1
$$

Where $i$ is the nominal interest rate and the inflation $\pi$ is the growth rate of the consumer prices index. Fisher explains this relation by the impact of inflation on the economy. Inflation not only depreciates the real revenue of interest rates but primarily distorts the prices of goods and services and therefore, according to Fisher, the real interest rates are lower than what would correspond with the simple margin between the nominal rates and the rate of inflation.

Further development of the quantity theory of money in the $20^{\text {th }}$ century was mostly influenced by two significant economic approaches - Keynesianism and Monetarism.

In the first half of the $20^{\text {th }}$ century the all-round British genius, especially economist and mathematician John Maynard Keynes, the inheritance of whom hugely affected all fields of economics, became the scholastic and ideological founder of the Keynesian thinking. Keynes' book “The General Theory of Employment, Interest and Money" from 1936 became the principal work of the main stream of the economic theory at that time.

Keynes did not limit himself only to work with the above-mentioned macroeconomic aggregates but he worked especially with the aggregate $\mathrm{M}$ with regard to its relation to the variables such as unemployment, investment, interest rates, economic growth, budget deficit etc. He treated the aggregate $\mathrm{M}$ from a different point of view - he accentuated another attribute of money which is, beside the velocity of its turnover, its liquidity. He viewed the supply of money in circulation as money demand. Keeping different forms of money can have different motives - either money is kept for the purpose of purchasing goods and services - i.e. the transaction (circulation) motive, or it is kept for the reserve purpose - i.e. the canniness motive, or the hoarding motive (reserve). Based on this we can see that particular forms of money (kept for particular purposes) differ significantly depending on their liquidity. Transaction money (the circulation motive) has a cash or undated form in contrast with money kept as a reserve (the canniness motive) which usually has the form of time deposit or money kept as a monetary asset. And the size, intensity and preference of these motives determine the level of money liquidity, or: an asset is the more money, the more it is liquid, and it is the more liquid, the lower are the costs related to its exchange. 
Keynes' contribution and influence in his times was almost boundless. He used scholarly methods to prove the necessity of state interventions into the economy with the positive impact on aggregate demand (of consumptions and investment) and on employment. In the field of the quantity theory of money, his major contribution, among others, is the different concept of money and its forms based on its liquidity. Keynes was the first to lay the claim of dividing money based on money demand into particular aggregates according to the level of their liquidity ${ }^{11}$. At present, work with monetary aggregates is an inseparable part of the execution of the monetary policy of central banks. They monitor not only the absolute volume of particular aggregates, but in particular the changes and transfers among them.

A part of Keynes' heritage closely related to the theory of money is also a modified concept of the quantity equation of money, the so-called Cambridge equation of equilibrium ${ }^{12}$. In the Cambridge equation, Keynes focuses more on money demand than on money supply governed by central banks. Particular equations also differ in the concept of the aggregate of the velocity of money turnover $\mathrm{V}$. In the classical quantity equation of equilibrium, associated with Fisher, money circulates at a relatively fixed rate and serves rather as a medium of exchange. On the contrary in the Cambridge equation, money acts as a store of value and its velocity of turnover depends on the desirability of households to keep cash. Economists associated with Cambridge University, besides Keynes for example Alfred Marshall, A.C. Pigou and others prove that a certain portion of issued money will not be used for transactions; but is, for the canniness and security purposes, kept by households in cash. This portion of cash is commonly represented as $\mathrm{k}$ and if it is regarded in a short-term period as fixed, then according to the Cambridge equation the velocity of money turnover $\mathrm{V}$ equals to the inversion value of $\mathrm{k}$. The Cambridge equation is thus:

$$
\mathrm{M} \cdot 1 / \mathrm{k}=\mathrm{PQ}
$$

The development of economic thinking in the last third of the $20^{\text {th }}$ century was significantly influenced by the so-called Chicago school of economics which began focusing on the quantity theory of money from the monetary point of view. This monetary stream led into the movement represented by the principal representative of the liberal economic theory and of the Laissez faire doctrine Milton Friedman.

11 J.M. Keynes, The general theory of employment, interest and money, 1963.

12 M. Keynes, The General Theory of Employment, Interest and Money Chapter 2 : The Postulates of the Classical Economics, 2012. 
Keynes' relation between the volume of money and other quantities in the transaction equation is not as simple as it may seem. The quantities are affected by many, already mentioned, factors - liquidity of money, devaluation of money due to inflation, unemployment, consumers' preferences, etc. Monetarists find this relation more direct. In case the economy is not suffering from intense changes and consumers' preferences are stable as the result of stable expectation of future revenue, and the velocity of money turnover $\mathrm{V}$ (the ratio of gross domestic product and the amount of money, i.e. GDP/M) is relatively fixed, then it is possible to influence prices and therefore the economic activity through the supply of money M. Friedman formulated this clearly in a range of his papers and works, such as in the paper "The Role of Monetary Policy" from 1968, "The Optimum Quantity of Money: And Other Essays" from 1976, "Monetary Policy: Theory and Practice" from 1982 and in many others.

\section{Monetary Aggregates in Current Monetary Policy}

The mutual correlation between the growth of the price level $\mathrm{P}$ and the increase of money supply $\mathrm{M}$ was proved by lots of research work performed independently of each other in many advanced countries ${ }^{13}$. If price stability is to be kept, which is the main aim of central banks' activities at present, the principal target is to maintain an equable growth of money supply and also a growth of production ${ }^{14}$. In other words: there is inflation if the left side of the equation, or the growth of money supply (on condition that the velocity of money turnover $\mathrm{V}$ is fixed), advances the right side of the equation, i.e. the growth of a product - offered goods and services ${ }^{15}$. In his paper "Inflation: Causes and Consequences" from 1963, Friedman describes that inflation is always and everywhere a monetary phenomenon.

Mishkin defines the inflation targeting regime as consisting of five elements: (i) a public announcement of a numerical inflation target (a point or a range) for a given time horizon, (ii) an institutional commitment to price stability as the ultimate goal of the monetary policy with other goals subordinate to it, (iii) the adoption of an information strategy that does not solely use variables such as monetary aggregates or the exchange rate as parameters to determine the policy

13 G.D. Hansen, Indivisible labor and the business cycle, 1985; R.M. Edge, Time to bulid, time to plan, habit persistence and the liquidity effect, 2007; S. Dressler, The cyclical effect of monetary policy regimes, 2007; R. Sustek, Monetary Aggregates and the Business cycle, 2010.

14 R. Murphy, Lost in a Maze of Monetary Aggregates, 2011.

15 M. Friedman, The Role of Monetary Policy, 1968. 
instruments, (iv) a higher degree of transparency of the monetary policy strategy through communication with the public and the markets in relation to the plans, goals, and decisions of the monetary authorities, and (v) assigning the central bank greater responsibility in meeting inflation targets ${ }^{16}$.

According to Bernanke ${ }^{17}$, the inflation targeting regime is the best monetary policy strategy because (i) it improves communication between the public and the monetary authorities and thus increases the agents' capacity to forecast future inflation, and (ii) it disciplines the government's monetary policy, thus giving it credibility. Credibility is the most important aspect of monetary policy as it avoids problems caused by time inconsistency ${ }^{18}$.

If the monetary authority has high credibility, from the moment the announcement is made the agents will reduce their inflationary expectations, which will lead to a reduction in the cost of inflation. If the monetary policy deviates from the target in favor of discretionary conduct a so-called inflation bias is created. This discretionary conduct can be used to provide liquidity to the economy and, therefore, growth.

Together with the establishment of this new economic concept of the quantity theory of money and inflation, these thoughts were increasingly brought to the notice of operative activities and monetary policies of central banks ${ }^{19}$. Recently this has been facilitated by the boom of information technologies which enable modelling economic processes, or the relation of the above mentioned quantities, while putting emphasis on the supply of money in circulation and its impact on inflation, by means of various economic-mathematical models ${ }^{20}$.

Experience shows that at present central banks pay an extraordinary attention to the volume of money supply ${ }^{21}$. The main issue they have been facing is how to determine the volume of the money supply part which a bank uses for the application of its issuing and corrective policy. This takes us back to the above mentioned fact of different liquidity of different forms of money which are cumulatively and for the purpose of monetary equilibrium equation defined

16 F. Mishkin, Inflation Target in Emergent Market Countries, NBER Working Papers 2011/17.

17 B. Bernanke, Inflation Targeting: Lesson from the International Experience, Princeton University Press, New Jersey 1999.

18 R. Barro, D. Gordon, Rules, Discretion and Reputation in a Model of Monetary Policy, Journal of Monetary Economics 1983/12; F. Kydland, E. Prescott, Rules Rather than Discretion: The Inconsistency of Optimal Plants, Journals of Political Economy 1977/85; G. Calvo, On the Time Consistency of Optimal Policy in Monetary Economy, Econometrica 1978/45/4.

19 M.A. Akhtar, Understanding Open Market Operation, 2015.

20 M. Boermans, B. Moore, Locked-in and Sticky textbooks, 2009.

${ }^{21}$ J.B. Carlson, B.D. Keen, MZM: A monetary aggregate for 1990's., 2006. 
as the aggregate M. Central banks apply methodical and structural distinction of the aggregate $\mathrm{M}$ into its particular elements which are carefully monitored with regard to their absolute amount as well as to the mutual transfer of their volume. The aggregate M1 is sometimes used for transaction money (narrow money), it is the most significant and the most monitored aggregate. According to the methodology of central banks in EU, M1 includes money in circulation (i.e. banknotes and coins) as well as the balance which can be immediately transferred to money in circulation or used for cashless payments, e.g. one-day deposits. This is the most liquid monetary aggregate. The aggregate M2 comprises of the aggregate M1 and moreover of the deposits due within two years and the deposits which are subject to three months' notice. Depending on liquidity, these deposits may be transferred to the elements of narrow money but in some cases there may be some restrictions such as the necessity of terminating the deposit by a notice, delay, penalty or charges. The definition of the aggregate $\mathrm{M} 2$ reflects the interest in analyzing and monitoring the monetary aggregate which besides money in circulation includes also liquid deposits. The aggregate $\mathrm{M} 2$ is called quasi money (near money). The same procedure may be used to create other aggregates in an analytical way with lower and lower rate of liquidity. The aggregate M3 consists of the aggregate M2 and of tradable tools issued by monetary financial institutions. This aggregate includes some tools of monetary market, particularly shares and investment certificates of market funds and repos. A high level of liquidity and price security guarantee that these instruments are near substitutes of deposits even though their liquidity is considerably lower. Incorporation of these instruments leads to the fact that the aggregate M3 is affected by substitution among different categories of liquid assets less than the narrower definitions of money are, and therefore it is more stable. The aggregate M3 is called broad money. The aggregate $\mathrm{M} 4$ consists of the aggregate $\mathrm{M} 3$ and of deposits in domestic non-bank institutions (e.g. co-accepted drafts and cheques). The aggregate M5 includes the aggregate M4 and other securities in the domestic currency (e.g. long-term obligations or bonds). Basic aggregates are illustrated in the following figure 1.

Why are central banks watching the particular aggregates so carefully? Simply because the amount and change of volume of particular aggregates are significant indicators of the economic performance of economy. A transfer of money from the aggregate $\mathrm{M} 1$ to the aggregate M2 signals increased saving behaviour in the economy ${ }^{22}$. The increased volume of the aggregate M2 is for commercial banks the main source for giving credits. Increased but cautious crediting of enterprises

${ }^{22}$ V.T. Gavin, F.E. Kydland, Endogenous money supply and the business cycle, 1999. 
by banks means an increased investment activity but also an increased flow of money to enterprises in other forms (financial means for operation, export etc.). Many analyses proved that the increase of the aggregate M2 is, after a particular lapse of time, followed by the growth of GDP ${ }^{23}$. A fast growth of this form of money accompanies a boom, its restriction is on the other hand often followed by recession, or can even have worse effects.

FIGURE 1: Monetary aggregates diagram

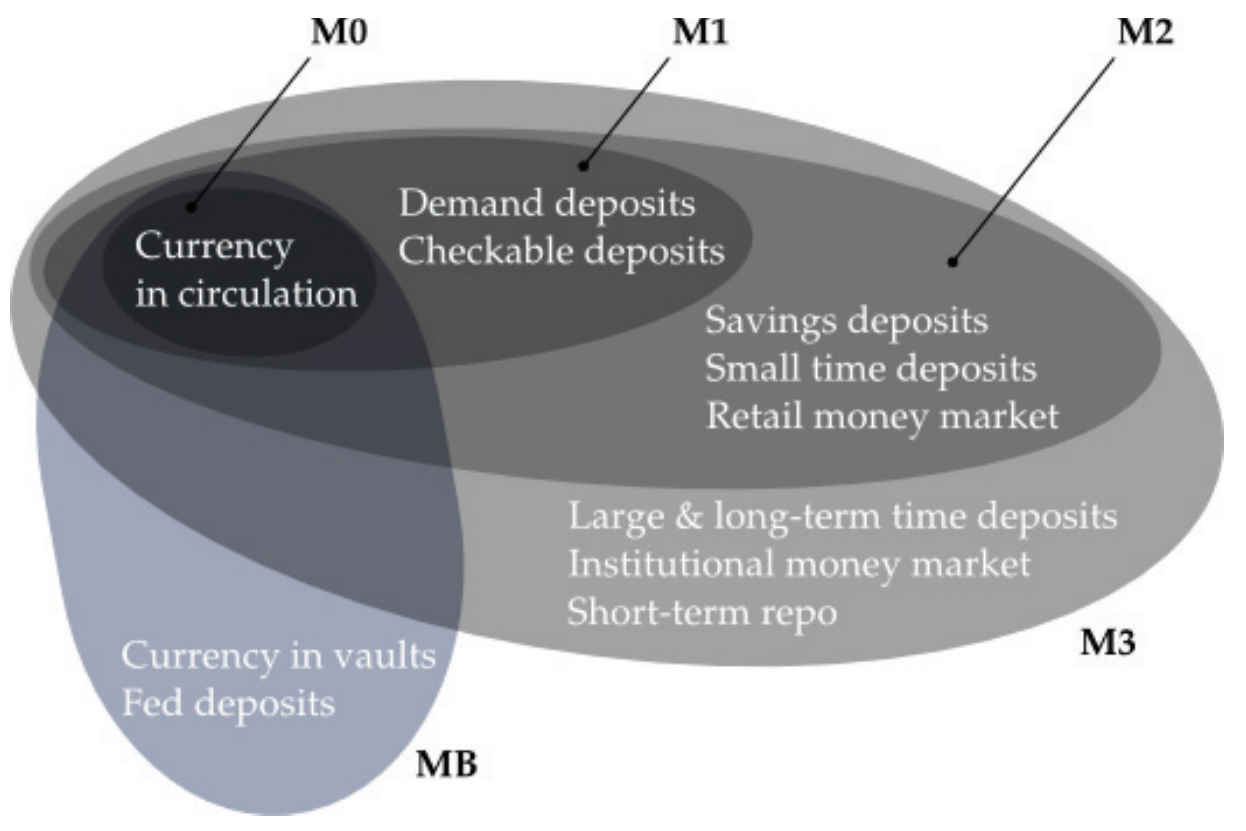

S o u r c e: Vita Smid, Monetary Aggregates Diagram, 2011, http://ze.phyr.us/monetary-aggregates-definition; accessed on 22.03.2017

Analytical monitoring of particular monetary aggregates is also an inseparable part of the monetary policy of central banks, especially in their activity related to inflation targeting; despite the fact that the development of monetary aggregates does not directly enter into central bank prognoses. The reason for this is that in the mode of inflation targeting, when the central bank checks the interest rates and withdraws excess money from the market, the development of money supply only reflects the economic development, measures of monetary

${ }^{23}$ G. Thayer, Investors should assume that inflation will exceed the Fed's target, 2013. 
policy and expectations of economic entities. Monetary aggregates may still serve as additional indicators for verifying the prognosis if they carry information about the current or future development of the economy. The analysis of the predicative ability of the monetary aggregates using the indicators of the so-called monetary overhang and the nominal and real monetary reserve is also a part of monetary policy analyses ${ }^{24}$.

The monetary overhang is defined as a percentage deviation of the real level of money supply from the level corresponding to the current position of the economy within the cycle and other fundamentals; and it is calculated based on a standard estimate of money demand. The nominal monetary gap is defined as a percentage deviation of the real aggregate M2 from the value it would have reached if it had grown at the rate reflecting the potential of the economy and the inflation target. The real monetary gap is defined as the nominal monetary gap adjusted by the difference between the real inflation and the inflation target. The monetary gap differs from the monetary overhang by the fact that in case of the monetary overhang the analysis is focused on how much the dynamics of M2 corresponds with the current development of the economy, while in case of the monetary gap the analysis is focused on how much the development of M2 corresponds with long-term equilibrium trends in the economy.

As it is difficult to divide the aggregate $\mathrm{M}$ into its particular elements according to a qualitative methodological point of view, it is also difficult to determine the optimum volume of these elements. This depends not only on the decisions of central banks but also on the particular economic situation of the country, on the priorities of the government and on its economic policy, on the structure of the state budget or on the state of the banking sector in the country. The practical application of the monetary policy thus depends on the priorities which are set in the particular country for the future status of national economy. Therefore it is not simple to analyse and compare monetary aggregates of different countries. At the end of the year, the central bank may determine the so-called target corridor of money supply, e.g. by dividing the year into four quarters and comparing the planned and expected amount of money supply with the previous year. This may be used for continual refinement of monetary policy targets, even several times a year. For refining future prospects, a wide range of information is taken into account, namely e.g. the current status of the economy, its growth or decline, pressures on price increase, exchange rate changes, commodity prices and many other facts, even those which are difficult to be estimated at that time.

${ }^{24}$ M. Woodford, Interest and Prices: Foundations of a Theory of Monetary Policy, 2003. 
Assessment of the aggregate $\mathrm{M}$ by central banks in an isolated way, without mutual relations and without respecting mutually different functions of money, does only little predicate about the particular status and fulfilling the issuing policy of the central bank. Money in the form of capital, which brings product and further revenue, income, wages and taxes into the state budget has a completely different function in monetary circulation than money in the form of money in circulation which only enables the exchange and consumption of the goods produced. Both are money of the aggregate $\mathrm{M}$ but with completely different monetary functions and consequences.

Central banks cannot simply replace deficit production of the economy or for example deficit of the state budget by new issue of cash money. Such issue would be unfair and harmful - it would give purchasing power to the first holders of this money as well as to those who do not participate in production and moreover, inflation consequences of this excess issue of money would destroy the purchasing power of all economic entities. At present, central banks take this fact into account when issuing money and use suitable regulatory measures and tools which allow governing money circulation not only as a global monetary mass but with respect to the differentiation of various forms of money and monetary functions of particular elements of the monetary aggregate.

\section{The ECB's definition of euro area monetary aggregates}

The primary objective of the Eurosystem, consisting of the European Central Bank (ECB) and the national central banks (NCBs) of the Member States which have adopted the euro, is to maintain price stability. As there is wide agreement that the development of the price level in the medium to long term is a monetary phenomenon, developments in the amount of money held by the public may reveal useful information about future price movements and thereby offer an important compass for the conduct of monetary policy. In addition, analysis of monetary aggregates can contribute to the general assessment of developments in the financial system and the broader economy.

A monetary aggregate can be defined as the sum of currency in circulation plus the outstanding amounts of certain liabilities of financial institutions which have a high degree of "moneyness" or liquidity in a broad sense. The Eurosystem has defined a narrow M1, an "intermediate" M2 and a broad aggregate M3. These aggregates differ with respect to the degree of moneyness of the assets included. According to the analysis conducted at the ECB and by its predecessor, the European 
Monetary Institute, broad euro area monetary aggregates might be less controllable in the short term but have more favourable properties than narrow ones in terms of their stability and their information content regarding price developments in the medium term. The monetary policy strategy of the Eurosystem requires identification of a monetary aggregate which is a stable and reliable indicator of inflation over the medium term. Therefore, the Governing Council of the ECB has decided to give the broad monetary aggregate $\mathrm{M} 3$ a prominent role in the monetary policy strategy by announcing a reference value for its annual growth rate.

The starting-point for the definition of euro area monetary aggregates is the consolidated balance sheet of the MFI sector (see Table 1). In general, the appropriate definition of a monetary aggregate largely depends on the purpose for which the selected aggregate is intended. Given that many different financial assets are substitutable, and that the nature and features of financial assets, transactions and means of payment are changing over time, it is not always clear how money should be defined and which financial assets belong to a certain definition of money. For these reasons, central banks usually define and monitor several monetary aggregates. These range from very narrow aggregates such as central bank money or base money, consisting of currency (i.e. banknotes and coins) and central bank deposits, to broader aggregates, which include currency, bank deposits and certain types of securities.

In defining money, both the microeconomic perspective of the individual holder of money and the empirical properties of monetary aggregates resulting from the joint behaviour of holders of money are relevant.

TABLE 1: Schematic consolidated balance sheet of the MFI sector for the euro area

\begin{tabular}{|l|l|}
\hline \multicolumn{1}{|c|}{ Assets } & \multicolumn{1}{c|}{ Liabilities } \\
\hline Loans & Currency in circulation \\
\hline Securities other than shares & Deposits of central government \\
\hline Shares and other equities & $\begin{array}{l}\text { Deposits of other general governments/other euro area } \\
\text { residents }\end{array}$ \\
\hline External assets & Money market fund shares/units and money market paper \\
\hline Fixed assets & Debt securities issued \\
\hline Remaining assets & Capital and reserves \\
\hline & External liabilities \\
\hline & Remaining liabilities \\
\hline
\end{tabular}

S o u r c e: European Central Bank. 
The ECB's definition of euro area monetary aggregates is based on the following:

A harmonised definition of the money-issuing sector. It consists of those entities that issue liabilities with a high degree of moneyness to non-MFIs located in the euro area (excluding central government). This sector comprises MFIs resident in the euro area.

A harmonised definition of the money-holding sector, which comprises all non-MFIs resident in the euro area (except central government). In addition to households, non-financial corporations and financial institutions which are not MFIs are included, as well as state and local governments and social security funds. Central governments are considered to constitute a "moneyneutral" sector, with one exception: central government liabilities with a monetary character (Post Office accounts, national savings accounts and Treasury accounts) are included as a special item in the definition of monetary aggregates.

The harmonised definitions of MFI liabilities categories. These make it possible to distinguish between MFI liabilities according to their degree of moneyness, while also taking into account the features of different financial systems.

Based on conceptual considerations and empirical studies, and in line with international practice, the Eurosystem has defined a narrow M1, an "intermediate" M2 and a broad aggregate M3. These aggregates differ with respect to the degree of moneyness of the assets included. Table 2 shows the definitions of the euro area monetary aggregates using the definition of liabilities issued by the MFI sector (see Table 2) as well as by entities belonging to the central government sector (Post Offices, Treasuries) of the euro area. As noted above, these aggregates include only positions of residents of the euro area which are held with MFIs located in the euro area. Holdings by euro area residents of liquid assets denominated in foreign currency can be close substitutes for euro-denominated assets. Therefore, the monetary aggregates include such assets if they are held with MFIs located in the euro area.

Narrow money M1 includes currency, i.e. banknotes and coins, as well as balances that can immediately be converted into currency or used for cashless payments, i.e. overnight deposits.

"Intermediate" money M2 comprises narrow money M1 and, in addition, deposits with maturities of up to tw years and deposits redeemable at notice of up to three months. Depending on their degree of moneyness, such deposits can be converted into components of narrow money, but in some cases there may be restrictions involved, such as the need for advance notification, delays, penalties or fees. 
The definition of M2 reflects the particular interest in analysing and monitoring a monetary aggregate that, in addition to currency, consists of deposits which are liquid.

Broad money M3 comprises M2 and marketable instruments issued by the MFI sector. Certain money market instruments, in particular money market fund (MMF) shares/units and money market paper, and repurchase agreements are included in this aggregate. A high degree of liquidity and price certainty make these instruments close substitutes for deposits. As a result of their inclusion, M3 is less affected by substitution between various liquid asset categories than narrower definitions of money, and is more stable.

TABLE 2: Definitions of euro area monetary aggregates

\begin{tabular}{|l|c|c|c|}
\hline \multicolumn{1}{|c|}{ Liabilities } & M1 & M2 & M3 \\
\hline Currency in circulation & $\mathrm{X}$ & $\mathrm{X}$ & $\mathrm{X}$ \\
\hline Overnight deposits & $\mathrm{X}$ & $\mathrm{X}$ & $\mathrm{X}$ \\
\hline Deposits with agreed maturity up to 2 years & & $\mathrm{X}$ & $\mathrm{X}$ \\
\hline Deposits redeemable at notice up to 3 months & & $\mathrm{X}$ & $\mathrm{X}$ \\
\hline Repurchase agreements & & & $\mathrm{X}$ \\
\hline Money market fund (MMF) shares/units and money market paper & & & $\mathrm{X}$ \\
\hline Debt securities up to 2 years & & & $\mathrm{X}$ \\
\hline
\end{tabular}

S o u r c e: European Central Bank.

As was explained the primary objective of the Eurosystem is to maintain price stability. This is laid down in the Treaty on the Functioning of the European Union, Article 127 (1). Without prejudice to the objective of price stability, the Eurosystem shall also support the general economic policies in the Union with a view to contributing to the achievement of the objectives of the Union. These include inter alia full employment and balanced GDP growth.

Monetary aggregates can be used as an auxiliary indicator for verifying the trend of GDP if they contain information on the present or future development of the economy. The ECB therefore analyses, along with numerous other economic indicators, the development of monetary aggregates. ECB summarizes the analysis of the information content of the monetary aggregates using the "monetary overhang".

The monetary overhang is defined as the percentage deviation of the actual money supply level from the level corresponding to the current position of the economy in the cycle and other fundamentals. It is calculated based on the 
standard estimate of money demand. The nominal money gap is defined as the percentage deviation of the actual M2 stock from the level it would reach if it grew at the rate reflecting the potential of the economy and the inflation target. The real money gap is defined as the nominal money gap "adjusted" for the difference between consumer price index (CPI) inflation and the inflation target. The money gap concept differs from the monetary overhang in that in the case of the latter we analyse the extent to which M2 growth is in line with the actual development of the economy, whereas in the case of the former we investigate the extent to which M2 growth is in line with the long-term equilibrium trends in the economy.

Unequal and imbalanced deviations of GDP growth supported by quantitative easing could bring some signal risks to price stability over the medium term. This causality is based on the well-known relationship between monetary growth, inflation, real GDP growth and changes in velocity. It embodies the definition of price stability (in ECB increase in the HICP of below 2\% per annum) as announced and unchanged by the Governing Council of the ECB in October 1998. The derivation of the reference value was further based on medium-term assumptions regarding the trend of real GDP growth and the trend in the velocity of circulation of M3. For the medium-term trend in real GDP growth for the euro area, an assumption of 2-2\% per annum was made, in line with estimates from both international organisations and the ECB. In setting the assumption for the decline in the velocity of circulation, various approaches were applied.

Taking into account these assumptions for the medium-term trends in real GDP growth and velocity, and based on its intention to maintain HICP inflation for the euro area below $2 \%$, the Governing Council decided to set its first reference value for M3 growth at 4\%o per annum. Money growth substantially in excess of this value would tend to signal inflationary risks if the relationship between M3, prices and real GDP underlying the velocity trend decline of \%o to $1 \%$ remains stable.

Although several of the components used in the derivation of the reference value were expressed in the form of a range, the Governing Council has decided to announce a single reference rate for monetary growth, rather than a range. Announcing a reference range might have been falsely interpreted by the public as implying that interest rates would be changed automatically if monetary growth were to move outside the boundaries of the range. 


\section{Summary and conclusion}

The ECB similarly to most of the central banks, concentrates mostly on the stability of consumer prices. Practically, price stability does not mean changelessness of prices but their slow increase. The increase of prices corresponding with price stability should include a statistical deviation upwards which occurs at measuring the increase of prices, and should also give the necessary scope for slight changes of price relationships which happen in every economy with an effective price system all the time.

At present, the dominant activity of central banks related to the monetary policy is primarily establishing interest rates and executing operations on the free market. The issuing activity of central banks is often being marginalized. Nevertheless, the possibilities of central banks to influence the performance of the economy through the interest rates are quite limited. Commercial banks secure their sources first of all on the primary market, or by means of trade among themselves on the bank-to-bank market and the policy of central banks is effective only little. This can be seen even at present when the policy of minimum rates established by central banks is not able to support the economy and its growth.

On the other hand, a competent issue of money and regulation of the monetary aggregate $\mathrm{M}$ represents a more efficient monetary policy tool aiming at economic recovery and sustainable growth. Central banks must carefully analyze also the internal structure of the aggregate $\mathrm{M}$, consisting of the aggregate M1 to M5, and adjust also other tools from a wide range of monetary policy instruments. Central banks must be prospective in their issuing activity because an excess issue of money in its consequence always leads to the increase of prices and its impact on the real product in a long-term perspective is none.

To sum it up, it is clear that

- inflation is a monetary phenomenon which follows rather from faster increase of the amount of money (left side of the transaction equation) than by the product (right side of the transaction equation),

- there is only one efficient treatment of inflation, which is a lower rate of money supply growth (executed by different monetary policy tools),

- treatment of inflation is long-term and the costs of disinflation are always high, mostly related to the decline of the product growth dynamics and to the increase of unemployment. 
There is broad consensus that the development of the price level is a monetary phenomenon in the medium to long term. Consequently, the Governing Council of the ECB has decided that money will be accorded a prominent role in the Eurosystem's monetary policy strategy. This role was signalled by the announcement of a reference value for the growth rate of the broad monetary aggregate M3 of 4 \%o per annum by the Governing Council in December 1998. The derivation of this rate embodies the Eurosystem's definition of price stability. It is based on medium-term assumptions regarding real GDP growth and the trend decline in the velocity of circulation of M3. In order to achieve its primary objective of price stability, it is important for the Eurosystem to analyse closely the development of this aggregate against the reference value and to monitor other monetary aggregates.

\section{References}

Akhtar Mansuri A., Understanding Open Market Operation, Federal Reserve Bank of New York, New York 2015.

Barbon Nicholas, A discourse concerning the new money lighter: in answer to Mr. Lock's Considerations about raising the value of money, McMaster University Press, Canada 1971.

Barro Robert, Gordon D'Arcy, Rules, Discretion and Reputation in a Model of Monetary Policy, Journal of Monetary Economics 1983/12.

Bernanke Ben, Inflation Targeting: Lesson from the International Experience, Princeton University Press, New Jersey 1999.

Boermans Martin, Moore Bassett, Locked-in and Sticky textbooks, John Wiley and Sons, New York 2009.

Calvo Guillermo, On the Time Consistency of Optimal Policy in Monetary Economy, Econometrica 1978/45/4.

Carlson John, Keen Bolf, MZM: A monetary aggregate for 1990's, American Economic Review 1996.

European Central Bank, https://www.cnb.cz/ en/statistics/money_and_banking_stat/mbs _harmonisation/mbs_harmonisation_aggregates.html; accessed on 23.03.2017.

Dressler Scott, The cyclical effect of monetary policy regimes, International Economic Review 2007/48 (5), p. 551.

Edge Rick M., Time to bulid, time to plan, habit persistence and the liquidity effect, Journal of Monetary Economics 2007/54 (2007), p. 1644.

Fieser James, David Hume - Essay, Moral, Political and Literary, 2006, www:http://iep.utm. edu/humeessa; accessed on 20.03.2017.

Fisher Irving, The Purchasing Power of Money: Its Determination and Relation to Credit, Interest, and Crises, The Macmillan, New York 1922.

Frait Jan, Zednicek Roman, Monetární politika, neutralita a superneutralita peněz, Bankovnictví 2001/18 (4), pp. 19-25. 
Friedman Milton, The Role of Monetary Policy, American Economic Review 1968/58 (1), pp. $1-17$.

Friedman Milton, Money mischief, Management Press, Prague 1997.

Gavin Thomas, Kydland Finn E., Endogenous money supply and the business cycle, Review of Economic Dynamics 1999/2 (1999), p. 347.

Hansen Garry D., Indivisible labor and the business cycle, Journal of Monetary Economics 1985/16 (1985), p. 309.

Keynes John M., The General Theory of Employment, Interest and Money, Czech Academy of Sciences, Prague 1963.

Keynes John M., The General Theory of Employment, Interest and Money Chapter 2 : The Postulates of the Classical Economics, Oxford University Press, Oxford 2012.

Kydland Finn E., Prescott Edward, Rules Rather than Discretion: The Inconsistency of Optimal Plants, Journals of Political Economy 1977/85.

Mishkin Frederic, Inflation Target in Emergent Market Countries, NBER Working Papers 2011/17.

Murphy Robert, Lost in a Maze of Monetary Aggregates, Mises Institute: Austrian School of Economics 2011.

Schuler Kurt, Monetary Equilibrium - the Goal of Monetary Policy, The Fed and Central Banks, New York 2011.

Sowell Thomas, On classical economics, Yale University Press, New Haven 2006.

Sustek Roman, Monetary Aggregates and the Business cycle, Journal of Monetary Economics 2010/57 (4), p. 451.

Thayer Gert, Investors should assume that inflation will exceed the Fed's target, Wells Fargo Advisors, Orlando 2013.

Tobin James, The Interest Elasticity of Transaction Demand for Cash, Review of Economic Studies 1956/38 (1956), p. 241.

Twomey Brandon, The Taylor Rule: an Economic Model for Monetary policy, Economics basics, Chicago 2017.

Vita Smid, Monetary Aggregates Diagram, 2011, http://ze.phyr.us/monetary-aggregates-definition; accessed on 22.03.2017.

Woodford Michael, Interest and Prices: Foundations of a Theory of Monetary Policy, Princeton University Press, New Jersey 2003.

Richard POSPISIL

\section{AGGREGATY PIENIĘŻNE I AKTUALNE CELE EUROPEJSKIEGO BANKU CENTRALNEGO}

(Streszczenie)

Obecne łagodzenie ilościowe wprowadzone do polityki pieniężnej banków centralnych ma bezprecedensowy wpływ na równowagę monetarną i politykę monetarną jako całość. Kontrola podaży pieniądza i ustalanie stóp procentowych są to główne działania banków centralnych. Dzięki emisji pieniądza banki centralne bezpośrednio wpływają na zachowanie gospodarstw domowych, firm, 
rynków finansowych i państwa. Strategia polityki pieniężnej Europejskiego Banku Centralnego wymaga określenia agregatów monetarnych, które w perspektywie średnioterminowej są stabilnym i wiarygodnym wskaźnikiem inflacji. Jest to ściśle związane ze wzrostem realnego PKB i stopą bezrobocia. Podczas monitorowania kwestii pieniądza konieczne jest skupienie się nie tylko na jego wielkości, ale także na cechach i funkcjach pieniężnych. Celem pracy jest analiza indywidualnych agregatów monetarnych wyemitowanych pieniędzy w strefie euro, ich odmiennego wpływu na gospodarkę, co w istotny sposób oddziałuje na średniookresowy wzrost rzeczywistych wyników krajowych. W artykule omówiono wyliczenie agregatu do jego różnych elementów w Europejskim Banku Centralnym, co jest znaczące dla realizacji celów polityki pieniężnej.

Słowa kluczowe: agregaty pieniężne; polityka pieniężna; inflacja; PKB; Europejski Bank Centralny 